\title{
Serpulina pilosicoli sp. nov., the Agent of Porcine Intestinal Spirochetosis
}

\author{
DARREN J. TROTT, ${ }^{1 *}$ THADDEUS B. STANTON,${ }^{2}$ NEIL S. JENSEN,${ }^{2}$ GERALD E. DUHAMEL, ${ }^{3}$ \\ JOHN L. JOHNSON, ${ }^{4}$ AND DAVID J. HAMPSON ${ }^{1}$ \\ School of Veterinary Studies, Murdoch University, Murdoch, Western Australia 6150, Australia ${ }^{1}$; Physiopathology \\ Research Unit, National Animal Disease Center, Agricultural Research Service, U.S. Department of Agriculture, \\ Ames, Iowa 50010²; Department of Veterinary and Biomedical Sciences, University of Trebraska-Lincoln, \\ Lincoln, Nebraska 68583-09053; and Department of Anaerobic Microbiology, Virginia \\ Polytechnic Institute and State University, Blacksburg, Virginia 24061-0305 ${ }^{4}$
}

\begin{abstract}
Phenotypic and genetic traits of porcine intestinal spirochete strain $\mathbf{P 4 3 / 6} / 78^{\mathrm{T}}\left(=\right.$ ATCC $\left.51139^{\mathrm{T}}\right)(\mathrm{T}=$ type strain), which is pathogenic and weakly beta-hemolytic, were determined in order to confirm the taxonomic position of this organism and its relationships to previously described species of intestinal spirochetes. In BHIS broth, $P 43 / 6 / 78^{\mathrm{T}}$ cells had a doubling time of 1 to $2 \mathrm{~h}$ and grew to a maximum cell density of $2 \times 10^{9}$ cells per $\mathrm{ml}$ at 37 to $42^{\circ} \mathrm{C}$. They hydrolyzed hippurate, utilized D-glucose, D-fructose, sucrose, D-trehalose, D-galactose, D-mannose, maltose, $N$-acetyl-D-glucosamine, D-glucosamine, pyruvate, $L$-fucose, D-cellobiose, and D-ribose as growth substrates, and produced acetate, butyrate, ethanol, $\mathrm{H}_{2}$, and $\mathrm{CO}_{2}$ as metabolic products. They consumed substrate amounts of oxygen and had a G+C content $(24.6 \mathrm{~mol} \%)$ similar to that of Serpulina hyodysenteriae $\mathrm{B}^{\mathrm{T}} \mathrm{T}^{\mathrm{T}}(25.9 \mathrm{~mol} \%)$. Phenotypic traits that could be used to distinguish strain $\mathrm{P43/6} / 7 \mathrm{P}^{\mathrm{T}}$ from $S$. hyodysenteriae and Serpulina innocens included its ultrastructural appearance (each strain $P 43 / 6 / 78^{\mathrm{T}}$ cell had 8 or 10 periplasmic flagella, with 4 or 5 flagella inserted at each end, and the cells were thinner and shorter and had more pointed ends than $S$. hyodysenteriae and $S$. innocens cells), its faster growth rate in liquid media, its hydrolysis of hippurate, its lack of $\beta$-glucosidase activity, and its metabolism of D-ribose. DNA-DNA relative reassociation experiments in which the $S 1$ nuclease method was used revealed that $P 43 / 6 / 78^{\mathrm{T}}$ was related to, but was genetically distinct from, both $S$. hyodysenteriae $\mathbf{B}^{\mathrm{T}}{ }^{\mathrm{T}}$ (level of sequence homology, 25 to $32 \%$ ) and $S$. innocens $\mathrm{B256}^{\mathrm{T}}$ (level of sequence homology, 24 to $25 \%$ ). These and previous results indicate that intestinal spirochete strain $\mathrm{P} 43 / 6 / 78^{\mathrm{T}}$ represents a distinct Serpulina species. Therefore, we propose that strain $\mathrm{P} 43 / 6 / 78$ should be designated as the type strain of a new species, Serpulina pilosicoli.
\end{abstract}

Porcine intestinal spirochetosis or spirochetal diarrhea is a disease of swine that are between 4 and 20 weeks old but typically occurs within 7 to 14 days after weaning $(7,39)$. The clinical signs of this disease include mucus-containing, usually nonbloody diarrhea; poor feed conversion; and depressed growth rates $(1,7,31,40)$. The characteristic histological feature that distinguishes porcine intestinal spirochetosis is a dense mat or false brush border of spirochete cells which are closely packed parallel to one another and are attached by one end to the colonic epithelium $(4,7,14,40)$. Such cells are not typical of infections caused by Serpulina hyodysenteriae (the agent of swine dysentery), but have been found in humans colonized by intestinal spirochetes, where their clinical significance is unclear $(8,22)$.

The etiologic agent of porcine intestinal spirochetosis was first described in 1980 by Taylor et al. (40). These investigators successfully isolated an intestinal spirochete, designated strain $\mathrm{P} 43 / 6 / 78^{\mathrm{T}}(\mathrm{T}=$ type strain), and reproduced clinical signs and lesions typical of the disease in pigs that were orally challenged with pure cultures of this bacterium. Colonies of this spirochete were found to be weakly beta-hemolytic on blood agar media. Electron microscopy revealed that strain $\mathrm{P} 43 / 6 / 78^{\mathrm{T}}$ cells had a typical spirochete ultrastructure and that each cell had 8,10 , or 12 periplasmic flagella (4 to 6 periplasmic flagella were inserted into the protoplasmic cylinder at each end of the cell, with the free ends overlapping in the middle of the cell) $(12,40)$. This feature distinguished $\mathrm{P} 43 / 6 / 78^{\mathrm{T}}$ from $S$. hyodys-

* Corresponding author. Phone: 619360 2247. Fax: 6193104144. Electronic mail address: dtrott@numbat.murdoch.edu.au. enteriae and the nonpathogenic spirochete Serpulina innocens, which typically have 16 to 24 and 20 to 28 periplasmic flagella per cell, respectively $(18,30)$. Despite its apparent significance as a swine pathogen, strain $\mathrm{P} 43 / 6 / 78^{\mathrm{T}}$ has not been extensively characterized in terms of its physiological and biochemical properties, and its taxonomic status has not been conclusively determined previously.

In this study, we determined ultrastructural, physiological, and genomic characteristics of strain $\mathrm{P} 43 / 6 / 78^{\mathrm{T}}$. Our results, together with the results of previous investigators, support the hypothesis that strain $\mathrm{P} 43 / 6 / 78^{\mathrm{T}}$ should be assigned to a new Serpulina species. We propose the name Serpulina pilosicoli for this spirochete. A major objective of this study was to obtain information that will be useful for studying this bacterium and for identifying other strains of $S$. pilosicoli.

\section{MATERIALS AND METHODS}

Bacterial strains and media. $S$. pilosicoli $\mathrm{P} 43 / 6 / 78^{\mathrm{T}}$ (= ATCC $51139^{\mathrm{T}}$ ) was originally obtained as a stock culture from D. J. Taylor, University of Glasgow, Glasgow, Scotland. S. hyodysenteriae B78 $\left(=\right.$ ATCC $\left.27164^{\mathrm{T}}\right)$ and $S$. innocens $\mathrm{B} 256^{\mathrm{T}}$ (= ATCC $29796^{\mathrm{T}}$ ) were obtained from the National Animal Disease Center culture collection. Cells were routinely grown at $38^{\circ} \mathrm{C}$ in $7 \mathrm{ml}$ of stirred BHIS broth under an atmosphere that initially contained $\mathrm{N}_{2}$ and $\mathrm{O}_{2}(99: 1)$, as described previously (36). Heart infusion broth containing heat-treated $\left(56^{\circ} \mathrm{C}, 30\right.$ $\mathrm{min}$ ) serum (HS broth) was used to determine which growth substrates were utilized (36). Bacterial growth was measured by monitoring the culture optical density at $620 \mathrm{~nm}\left(\mathrm{OD}_{620}\right)$ by using a path length of $18 \mathrm{~mm}$ and a Bausch \& Lomb Spectronic 70 spectrophotometer. Bacterial population densities were equated to culture optical densities by determining direct microscope counts with a Petroff-Hausser counting chamber.

Phase-contrast microscopy and electron microscopy. Wet mount preparations of $S$. pilosicoli $\mathrm{P} 43 / 6 / 78^{\mathrm{T}}$ and $S$. hyodysenteriae $\mathrm{B} 78^{\mathrm{T}}$ were prepared as described previously (37) and were photographed with an Olympus phase-contrast micro- 
scope equipped with an Olympus model PM-10AD automatic photomicrography system. Images were recorded on Kodak TMAX 100 film.

Actively dividing cells of $S$. pilosicoli $\mathrm{P} 43 / 6 / 78^{\mathrm{T}}, S$. hyodysenteriae $\mathrm{B} 78^{\mathrm{T}}$, and $S$ innocens $\mathrm{B} 256^{\mathrm{T}}$ were prepared for transmission electron microscopy by centrifuging $1.0-\mathrm{ml}$ portions of cultures at $2,000 \times \mathrm{g}$ and then resuspending the cells in $500-\mu \mathrm{l}$ portions of $10 \mathrm{mM}$ sodium phosphate buffer ( $\mathrm{pH} 7$ ). A $20-\mu \mathrm{l}$ sample of each suspension was negatively stained with an equal volume of $2 \%$ phosphotungstic acid ( $\mathrm{pH} 6$ for strain $\mathrm{B} 78^{\mathrm{T}}$ and $\mathrm{pH} 7$ for strain $\mathrm{P} 43 / 6 / 78^{\mathrm{T}}$ ), mounted on a carbon-reinforced 200-mesh copper grid coated with $2 \%$ Parlodion, and examined at $80 \mathrm{kV}$ with a Phillips model 410 transmission electron microscope Cell lengths and diameters were determined from electron micrographs of five individual cells.

Growth characteristics. S. pilosicoli $\mathrm{P} 43 / 6 / 78^{\mathrm{T}}$, S. hyodysenteriae $\mathrm{B} 78^{\mathrm{T}}$, and $S$. innocens $\mathrm{B} 256^{\mathrm{T}}$ cells were cultured in BHIS broth, and their optimal growth temperatures were determined by incubating culture tubes at a $45^{\circ}$ angle at 32 , 37,42 , and $47^{\circ} \mathrm{C}$ in a Lab-line orbital shaker at $200 \mathrm{rpm}$. The ability of each strain to grow in the presence of different $\mathrm{O}_{2}$ concentrations $(1,2,5,7,15$, and $20 \%)$ was determined with freshly inoculated cultures by removing an appropriate volume of gas from the headspace with an airtight syringe and injecting an equal volume of air. The $\mathrm{pH}$ range for growth was determined by adjusting the $\mathrm{pH}$ o the medium with $1 \mathrm{M} \mathrm{HCl}$ or $1 \mathrm{M} \mathrm{NaOH}$ in $0.2-\mathrm{pH}$ unit increments prior to inoculation. The final $\mathrm{pH}$ of each inoculated medium containing glucose was determined when the cultures reached their maximum population densities $\left(\mathrm{OD}_{620}\right)$. Population doubling times were estimated from standard growth curves. The strength of beta-hemolysis was determined by stab inoculating individual colonies into a segment of a Trypticase soy agar plate supplemented with $5 \%$ defibrinated bovine blood. The plates were then incubated at $37^{\circ} \mathrm{C}$ in a Coy anaerobic chamber filled with $\mathrm{N}_{2}-\mathrm{H}_{2}-\mathrm{CO}_{2}$ (85:10:5)

Biochemical tests. Gelatinase activity was determined by using the modified zymography method of Kleiner and Stetler-Stevenson (20). Cells of the three spirochete strains and a gelatinase-producing strain of Staphylococcus aureus (strain ATCC 25923) were grown in $7 \mathrm{ml}$ of BHIS broth supplemented with $4 \%$ gelatin $\left(\mathrm{OD}_{620}, 1.2\right.$ to 1.6$)$. The bacterial cells then were harvested by centrifugation at $12,100 \times \mathrm{g}$ for $10 \mathrm{~min}$ at $4^{\circ} \mathrm{C}$ and washed with $7 \mathrm{ml}$ of TBS buffer (10 $\mathrm{mM}$ Tris, $0.85 \% \mathrm{NaCl} ; \mathrm{pH} 7.4$ ). The resulting suspensions were centrifuged at 12 $100 \times g$ for $10 \mathrm{~min}$ at $4^{\circ} \mathrm{C}$, and the cells of each strain were suspended in $2 \mathrm{ml}$ of TBS buffer and sonicated at $50 \mathrm{~W}$ on ice three times $(30 \mathrm{~s}$ each) with a Branson model 250 Sonifier. The cellular debris was pelleted by centrifugation at 12,100 $\times g$ for $20 \mathrm{~min}$ at $4^{\circ} \mathrm{C}$, and the supernatant was collected and stored at $-70^{\circ} \mathrm{C}$ A $25-\mu$ l sample of each supernatant was mixed with an equal volume of $0.2 \times$ sample buffer $(0.4 \mathrm{M}$ Tris [pH 6.8], $5 \%$ sodium dodecyl sulfate [SDS], 20\% glycerol, $0.03 \%$ bromophenol blue), and the resulting preparation was loaded into the wells of an SDS-polyacrylamide gel $(10$ by 10 by $0.1 \mathrm{~cm} ; 4 \%$ [wt/vol] polyacrylamide stacking gel, $12 \%$ [wt/vol] polyacrylamide resolving gel containing $0.1 \%$ gelatin). Electrophoresis and staining of the gel were performed as recommended by Kleiner and Stetler-Stevenson (20).

Hydrolysis of esculin in HS broth cultures was determined by the method of Holdeman et al. (9); a Staphylococcus aureus ATCC 25923 culture and uninoculated media were included as controls. Hydrolysis of hippurate in BHIS broth cultures supplemented with $1 \%$ sodium hippurate was determined as described by Kinyon and Harris (18); uninoculated medium was included as a control. $\mathrm{H}_{2} \mathrm{~S}$ production was determined by using BHIS broth containing no L-cysteine or resazurin. A dry, sterile strip of Whatman no. 1 filter paper that had been presoaked in hot $5 \%$ lead acetate was suspended $1 \mathrm{~cm}$ above the level of the medium. The controls used included an $\mathrm{H}_{2} \mathrm{~S}$-producing strain of Salmonella typhimurium (strain 798) and Escherichia coli HB101, which did not produce $\mathrm{H}_{2} \mathrm{~S}$. The tubes were incubated at $38^{\circ} \mathrm{C}$ and were observed twice daily; a black discoloration that extended up the filter paper strip indicated that lead sulfide was being formed from evolved $\mathrm{H}_{2} \mathrm{~S}$. Enzyme profiles were determined by using the API ZYM system (13). The production of indole in broth cultures was determined as described previously (24).

Substrate utilization. Before individual substrates were examined, the minimum serum concentration that supported maximum growth in HS broth containing $0.4 \%$ (wt/vol) glucose was found to be $7 \%$ for both $S$. pilosicoli $\mathrm{P} 43 / 6 / 78^{\mathrm{T}}$ and $S$. innocens $\mathrm{B} 256^{\mathrm{T}}$. This concentration was used in media to determine which growth substrates were utilized. Potential growth substrates were prepared as filter-sterilized stock solutions $(14 \%, w t / v o l)$ and added to the medium to a final concentration of $0.4 \%$. Compounds that could not be filter sterilized were added to the basal medium before autoclaving. A $1 \%$ (vol/vol) inoculum of washed cells grown in BHIS broth was transferred into $7 \mathrm{ml}$ of HS broth containing a potential substrate, and the resulting preparation was incubated at $38^{\circ} \mathrm{C}$ for 5 days or until the maximum cell growth (highest culture optical density) was observed. If growth was detected, a $0.1-\mathrm{ml}$ sample was transferred into fresh media containing the same substrate. Growth yields (maximum $\mathrm{OD}_{620}$ values) were determined from these subcultures. When growth on a particular substrate only slightly exceeded (i.e., was $<0.3 \mathrm{OD}_{620}$ unit greater than) growth in medium without added substrate, cell densities were determined by direct counting. A substrate was considered a substrate that supported growth if the number of cells in a culture containing the substrate was more than fivefold greater than the number of cells in a culture containing no added substrate.

Analysis of fermentation products. Nongaseous end product contents were determined by using cultures of $S$. pilosicoli $\mathrm{P} 43 / 6 / 78^{\mathrm{T}}$ and $S$. innocens $\mathrm{B} 256^{\mathrm{T}}$ growing in $7 \mathrm{ml}$ of HS broth supplemented with $0.4 \%$ glucose. A HewlettPackard model 5890 gas chromatograph equipped with a model $7671 \mathrm{~A}$ automatic sampler was used to identify and quantify volatile fatty acids and alcohols (36).

Gases in culture atmospheres were identified and quantified by using a GowMac series 580 gas chromatograph. The culture medium was acidified to release $\mathrm{CO}_{2}$ by injecting $0.1 \mathrm{ml}$ of $0.1 \mathrm{M} \mathrm{HCl}$ into the culture through the rubber stopper. A $3-\mathrm{ml}$ sample was removed from the headspace with an airtight syringe and injected into the sample loop $(0.5 \mathrm{ml})$ of the gas chromatograph. $\mathrm{H}_{2}$ was detected by using nitrogen as the carrier gas, and $\mathrm{CO}_{2}, \mathrm{O}_{2}$, and $\mathrm{N}_{2}$ were detected by using helium as the carrier gas. The amount of $\mathrm{N}_{2}$ in the culture atmosphere was considered fixed. Consequently, the amount of $\mathrm{N}_{2}$ was determined and used as an internal standard to quantify other gases.

Antibiotic susceptibility. The susceptibilities of the three spirochete strains to 20 different antibiotics were determined by the agar dilution method of Kitai et al. (19). The antibiotics and concentrations that were tested are shown in Table 1. The antibiotics used included antibiotics commonly used for treatment of swine dysentery (carbadox, lincomycin, tiamulin, tylosin), as well as antibiotics used in selective media for isolating $S$. hyodysenteriae (spectinomycin, vancomycin, colistin, rifampin, spiramycin) (21). The ranges of antibiotic concentrations used were based on the mean inhibitory concentrations determined for $S$. hyodysenteriae (19). The antibiotics were prepared as $2,000-\mu \mathrm{g} / \mathrm{ml}$ stock solutions, filter sterilized, and added to sterile Trypticase soy agar containing $5 \%$ defibrinated bovine blood $\left(48^{\circ} \mathrm{C}\right)$ before the plates were poured. Cultures of $S$. pilosicoli $\mathrm{P} 43 / 6 / 78^{\mathrm{T}}, S$. hyodysenteriae $\mathrm{B} 78^{\mathrm{T}}$, and $S$. innocens $\mathrm{B} 256^{\mathrm{T}}$ were grown in BHIS broth until they reached an $\mathrm{OD}_{620}$ of 1.2 to 1.6 (approximately $3 \times 10^{8}$ to $1 \times 10^{9}$ cells per $\mathrm{ml}$ depending on the strain) and diluted with sterile TBS ( $\mathrm{pH}$ 7.4) to a culture density of $10^{7}$ cells per ml. A $10-\mu$ l sample of each suspension was deposited onto each antibiotic plate. The mean concentration of antibiotic which inhibited growth (prevented the appearance of hemolytic zones) after 4 days of incubation in a Coy chamber at $37^{\circ} \mathrm{C}$ was determined by using at least three replicates of each antibiotic dilution. Bacteria were inoculated onto plates without antibiotics as controls. Carbadox was obtained from Pfizer, New York, N.Y., and tiamulin was obtained from Fermenta, Kansas City, Mo. All other antibiotics were obtained from Sigma Chemical Co., St. Louis, Mo.

DNA analysis. For DNA homology studies, DNA was extracted from cells of S. pilosicoli $\mathrm{P} 43 / 6 / 78^{\mathrm{T}}$, S. hyodysenteriae $\mathrm{B} 78^{\mathrm{T}}$, and $S$. innocens $\mathrm{B} 256^{\mathrm{T}}$ as described previously $(3,16)$. Levels of DNA-DNA reassociation for the three strains were determined by the S1 nuclease method $(15-17)$.

To determine the DNA guanine-plus-cytosine $(\mathrm{G}+\mathrm{C})$ content, purified DNA was diluted in $0.3 \mathrm{ml}$ of $0.1 \times \mathrm{SSC}(1 \times \mathrm{SSC}$ is $0.15 \mathrm{M} \mathrm{NaCl}$ plus $0.015 \mathrm{M}$ sodium citrate) so that the final concentration was approximately $50 \mathrm{mg} / \mathrm{ml}$. The $\mathrm{G}+\mathrm{C}$ content was determined by the thermal denaturation method (27). DNA from $S$. hyodysenteriae $\mathrm{B} 78^{\mathrm{T}}(\mathrm{G}+\mathrm{C}$ content, 25 to $26 \mathrm{~mol} \%)$ was used as the standard.

\section{RESULTS}

Phase-contrast microscopy and electron microscopy. Phasecontrast micrographs of $S$. hyodysenteriae $\mathrm{B} 78^{\mathrm{T}}$ and $S$. pilosicoli $\mathrm{P} 43 / 6 / 78^{\mathrm{T}}$ are shown in Fig. $1 \mathrm{~A}$ and $\mathrm{B}$, respectively. Compared with cells of strain $\mathrm{B} 78^{\mathrm{T}}$, strain $\mathrm{P} 43 / 6 / 78^{\mathrm{T}}$ cells generally were shorter and thinner and their ends were less tapered. The cell dimensions were sufficiently different that it was possible to differentiate the cells of the two species by light microscopy.

Morphological characteristics determined from measurements obtained from electron micrographs of the spirochetes are shown in Table 2. The strain B $78^{\mathrm{T}}$ cells tended to taper to a blunt surface at both ends (Fig. 2A), and 8 to 12 periplasmic flagella were inserted in a V-shaped arrangement at each end of each cell, so that there were 16 to 24 periplasmic flagella per cell (Fig. 2B). The strain $\mathrm{B} 256^{\mathrm{T}}$ cells were identical to the strain $\mathrm{B} 78^{\mathrm{T}}$ cells except that they had 20 to 26 periplasmic flagella per cell. Compared with the cells of the other strains, $S$. pilosicoli $\mathrm{P} 43 / 6 / 78^{\mathrm{T}}$ cells were shorter and thinner with fewer waves, and each cell had at least one abruptly pointed end (Fig. $3 \mathrm{~A})$. Four or five periplasmic flagella were inserted in a line at each end of each cell (Fig. 3B), so that there were 8 or 10 periplasmic flagella per cell.

Growth characteristics. $S$. pilosicoli $\mathrm{P} 43 / 6 / 78^{\mathrm{T}}$ cells grew to the maximum population density when they were incubated at 37 and $42^{\circ} \mathrm{C}$, whereas the growth of $S$. hyodysenteriae $\mathrm{B} 78^{\mathrm{T}}$ and $S$. innocens $\mathrm{B} 256^{\mathrm{T}}$ cells was limited slightly at $42^{\circ} \mathrm{C}$ (the maximum culture $\mathrm{OD}_{620}$ was less than 1.0). No culture grew at 32 or $45^{\circ} \mathrm{C}$. Compared with strain $\mathrm{B} 78^{\mathrm{T}}$ and $\mathrm{B} 256^{\mathrm{T}}$ cells, strain $\mathrm{P} 43 / 6 / 78^{\mathrm{T}}$ cells tolerated a slightly higher level of $\mathrm{O}_{2}$ in the 
TABLE 1. Antibiotic susceptibilities of S. pilosicoli $\mathrm{P} 43 / 6 / 78^{\mathrm{T}}$, S. hyodysenteriae $\mathrm{B}^{\mathrm{T}}{ }^{\mathrm{T}}$, and $S$. innocens $\mathrm{B} 256^{\mathrm{T}}$

\begin{tabular}{|c|c|c|c|c|}
\hline \multirow{2}{*}{ Antibiotic } & \multirow{2}{*}{$\begin{array}{l}\text { Concn tested } \\
\quad(\mu \mathrm{g} / \mathrm{ml})\end{array}$} & \multicolumn{3}{|c|}{ Susceptibility $(\mu \mathrm{g} / \mathrm{ml})^{a}$} \\
\hline & & S. pilosicoli $\mathrm{P} 43 / 6 / 78^{\mathrm{T}}$ & S. hyodysenteriae $\mathrm{B}^{7} 8^{\mathrm{T}}$ & S. innocens $\mathrm{B} 256^{\mathrm{T}}$ \\
\hline Ampicillin & $1,10,50,100$ & 10 & $\mathrm{R}$ & 1 \\
\hline Carbadox $^{b}$ & $0.1,1,5,10$ & 0.1 & 0.1 & 0.1 \\
\hline Chloramphenicol & $1,5,10,50$ & 5 & 5 & 5 \\
\hline Colistin $^{c^{-}}$ & $50,100,200,500$ & $\mathrm{R}$ & $\mathrm{R}$ & $\mathrm{R}$ \\
\hline Erythromycin & $5,20,50,100$ & 100 & 100 & 100 \\
\hline Kanamycin & $10,20,50,100$ & 20 & 50 & 10 \\
\hline Lincomycin ${ }^{b}$ & $1,10,50,100$ & 1 & 1 & 1 \\
\hline Metronidazole & $0.1,1,10,20$ & 0.1 & 0.1 & 0.1 \\
\hline Nalidixic acid & $50,100,200,500$ & 200 & 500 & 200 \\
\hline Neomycin & $10,50,100,200$ & 100 & 200 & 200 \\
\hline Novobiocin & $10,20,50,100$ & 20 & 100 & 50 \\
\hline Polymixin B & $50,100,200,500$ & $\mathrm{R}$ & $\mathbf{R}$ & $\mathbf{R}$ \\
\hline Rifampin ${ }^{c}$ & $10,20,50,100,200$ & 20 & $\mathbf{R}$ & 20 \\
\hline Spectinomycin ${ }^{c}$ & $100,200,500$ & $\mathrm{R}$ & $\mathbf{R}$ & $\mathrm{R}$ \\
\hline Spiramycin & $10,20,50,100,200$ & 50 & $\mathbf{R}$ & $\mathrm{R}$ \\
\hline Streptomycin & $10,20,50,100$ & 50 & 50 & 10 \\
\hline Tetracycline & $1,5,10,20$ & 1 & 1 & 1 \\
\hline Tiamulin ${ }^{b}$ & $0.1,1,5,10$ & 0.1 & 0.1 & 0.1 \\
\hline Tylosin ${ }^{b}$ & $5,20,50,100$ & 5 & $\mathrm{R}$ & 20 \\
\hline Vancomycin $^{c}$ & $100,200,500$ & $\mathrm{R}$ & $\mathrm{R}$ & $\mathrm{R}$ \\
\hline
\end{tabular}

a Values are the lowest concentrations of antibiotics which inhibited hemolysis as determined by the agar dilution method of Kitai et al. (19). R, no inhibition of growth (zone of hemolysis) at the highest concentration tested.

${ }^{h}$ Antibiotic commonly used in the treatment of swine dysentery.

"Antibiotic commonly used in selective media for the growth and identification of $S$. hyodysenteriae.

culture headspace ( 7 instead of $5 \%$ ), grew over a broader $\mathrm{pH}$ range (pH 5.6 to 8.0 instead of $\mathrm{pH} 6.0$ to 8.0 for $\mathrm{B}^{\mathrm{T}} 8^{\mathrm{T}}$ and $\mathrm{pH}$ 6.5 to 8.0 for $\mathrm{B} 256^{\mathrm{T}}$ ), and produced a lower final $\mathrm{pH}$ after growth in BHIS broth (pH 5.6 instead of pH 5.9). Strain P43/

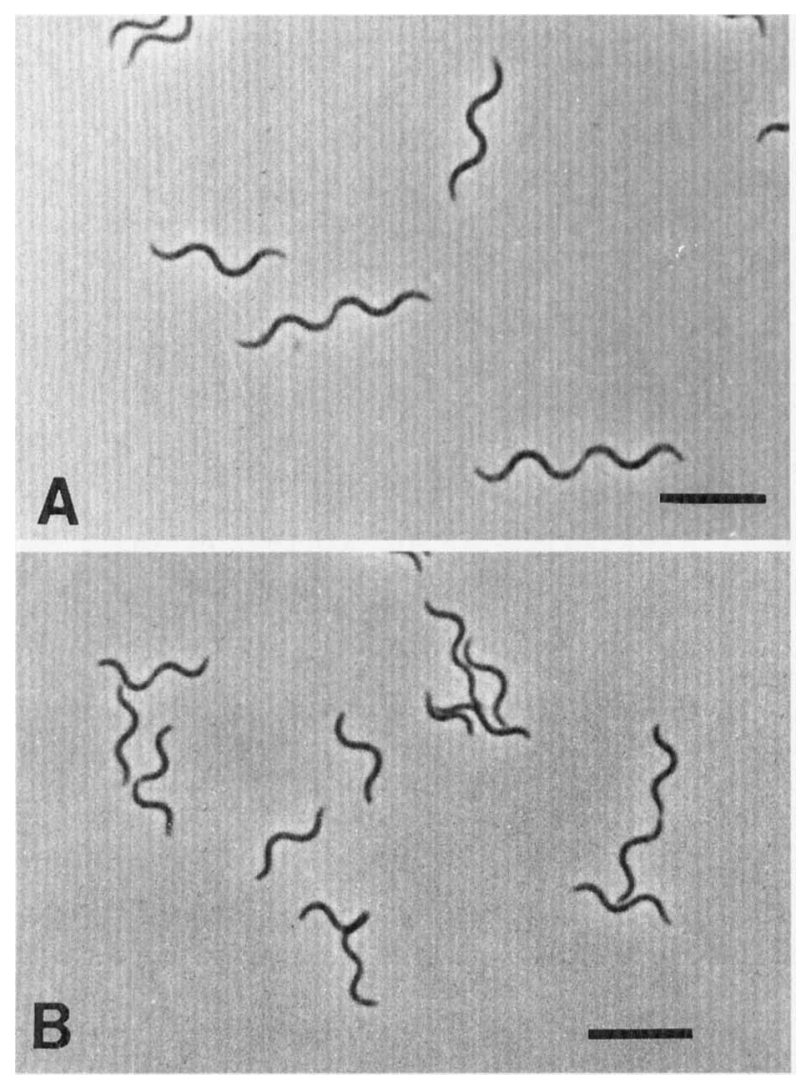

FIG. 1. Phase-contrast light micrographs showing cells of $S$. hyodysenteriae $\mathrm{B}^{7} 8^{\mathrm{T}}$ (A) and S. pilosicoli $\mathrm{P} 43 / 6 / 78^{\mathrm{T}}(\mathrm{B})$. Bar $=7 \mu \mathrm{m}$.
$6 / 78^{\mathrm{T}}$ also had a faster doubling time (1 to $2 \mathrm{~h}$ ) than strains $\mathrm{B}^{\mathrm{T}}$ and $\mathrm{B} 256^{\mathrm{T}}$ ( 3 to $5 \mathrm{~h}$ ) in BHIS broth.

Biochemical tests. Two bands of gelatin digestion (at 80 and $106 \mathrm{kDa}$ ) appeared after electrophoresis of cell lysates of the gelatinase-producing organism Staphylococcus aureus ATCC 25923. As determined by zymography, none of the spirochete lysates contained proteins that exhibited detectable gelatinase activity. All three spirochete species hydrolyzed esculin. Although both $S$. hyodysenteriae $\mathrm{B} 78^{\mathrm{T}}$ and $S$. innocens $\mathrm{B} 256^{\mathrm{T}}$ were negative in the test for hippurate hydrolysis, a strong positive reaction was obtained with $S$. pilosicoli $\mathrm{P} 43 / 6 / 78^{\mathrm{T}}$. As determined by the $\mathrm{H}_{2} \mathrm{~S}$ litmus test, Salmonella typhimurium 798 produced large amounts of $\mathrm{H}_{2} \mathrm{~S}$, each of the spirochete strains produced a moderate amount, and E. coli HB101 and the uninoculated media were both negative for this characteristic. The API ZYM profile of strain $\mathrm{P} 43 / 6 / 78^{\mathrm{T}}$ revealed that this organism was $\alpha$-glucosidase negative, $\alpha$-galactosidase positive, and $\beta$-glucosidase negative.

Substrate utilization. All three spirochete species used soluble sugars, pyruvate, D-glucosamine, and $N$-acetyl-D-glucosamine as energy sources (Table 3 ). Both strain P43/6/78 ${ }^{\mathrm{T}}$ cells and strain $\mathrm{B} 256^{\mathrm{T}}$ cells were able to metabolize the same monoand disaccharides as strain $\mathrm{B} 78^{\mathrm{T}}$ cells. In addition, $\mathrm{P} 43 / 6 / 78$ and $\mathrm{B} 256^{\mathrm{T}}$ cells were able to use D-cellobiose and $\mathrm{L}$-fucose for growth. Of the three spirochetes, only $\mathrm{P} 43 / 6 / 78^{\mathrm{T}}$ was able to use the pentose sugar D-ribose as a growth substrate. $\mathrm{P} 43 / 6 / 78^{\mathrm{T}}$ grew to higher cell densities than either $\mathrm{B} 78^{\mathrm{T}}$ or $\mathrm{B} 256^{\mathrm{T}}$ in HS broth containing no added substrate $\left(\mathrm{OD}_{620}, 1.0\right.$ [equivalent to $10^{8}$ to $3 \times 10^{8}$ cells per $\left.\mathrm{ml}\right]$ ). The spirochetes apparently used unidentified substrates in the serum, as no growth occurred in HS broth alone.

End products. All three species produced large amounts of acetate and small amounts of butyrate (Table 4). In addition, $\mathrm{P} 43 / 6 / 78^{\mathrm{T}}$ and $\mathrm{B} 256^{\mathrm{T}}$ produced small amounts of ethanol. All three organisms also produced approximately twice as much $\mathrm{H}_{2}$ as $\mathrm{CO}_{2}$. Oxygen added to the headspace atmosphere of cultures at concentrations of 1 to $7 \%$ (vol/vol) was consumed during growth $\left(<0.05 \% \mathrm{O}_{2}\right.$ was present at the maximum cell 


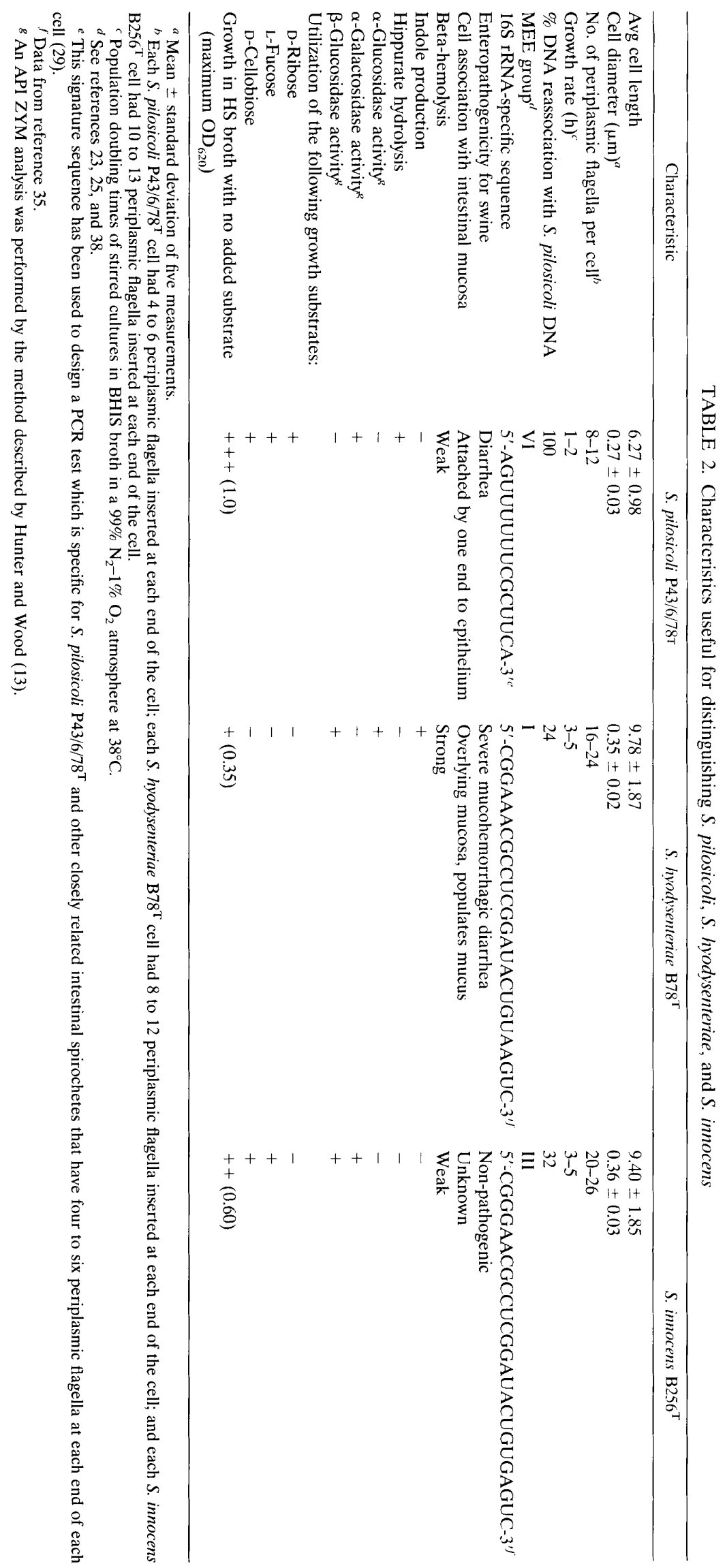



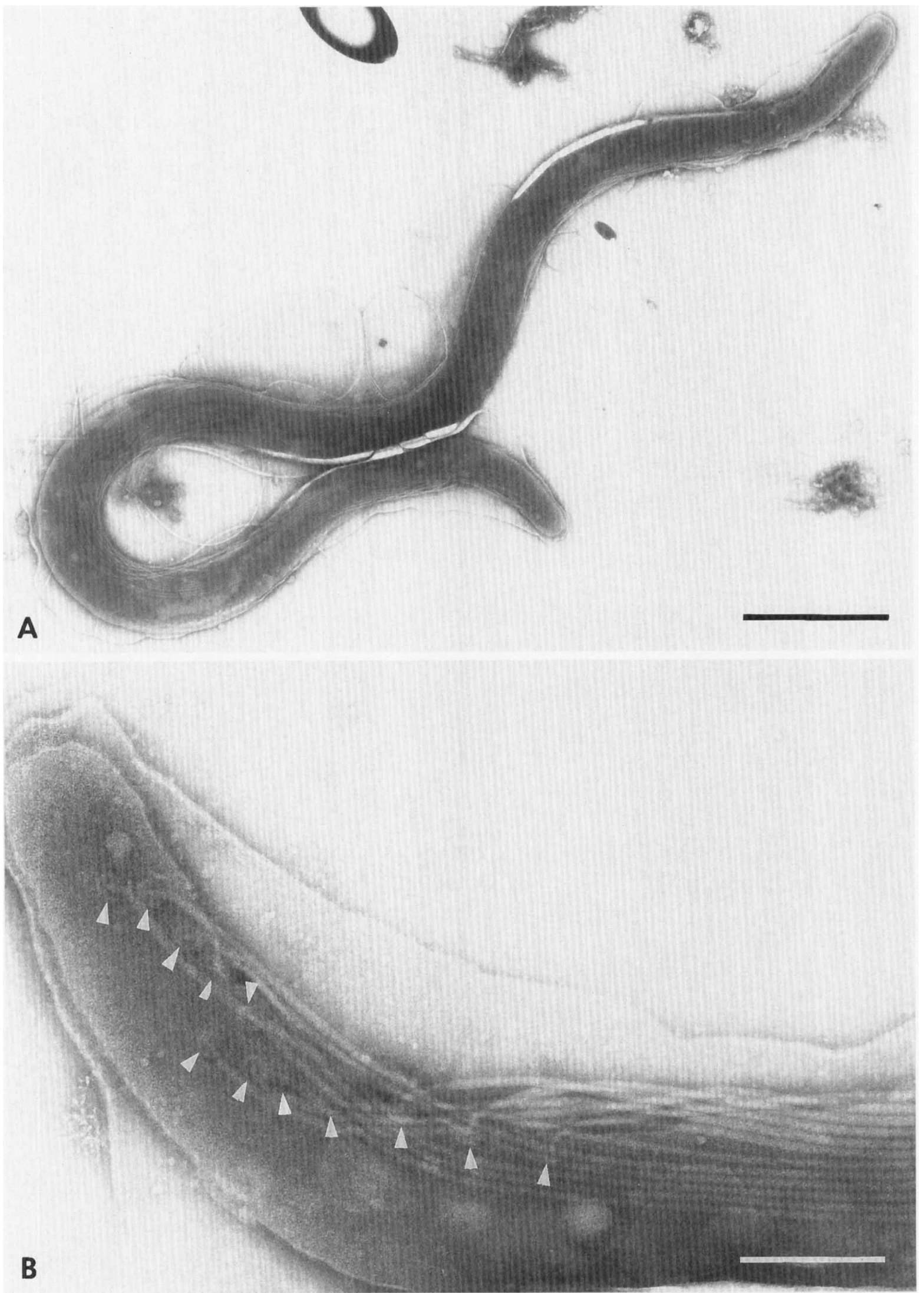

FIG. 2. (A) Electron micrograph of negatively stained whole cell of $S$. hyodysenteriae $B 78^{\mathrm{T}}$. The ends of the cell are blunt. Bar $=1.0 \mu \mathrm{m}$. (B) Electron micrograph of one end of a cell, showing 12 flagella and insertion discs in a V-shaped arrangement. Bar $=0.2 \mu \mathrm{m}$. 


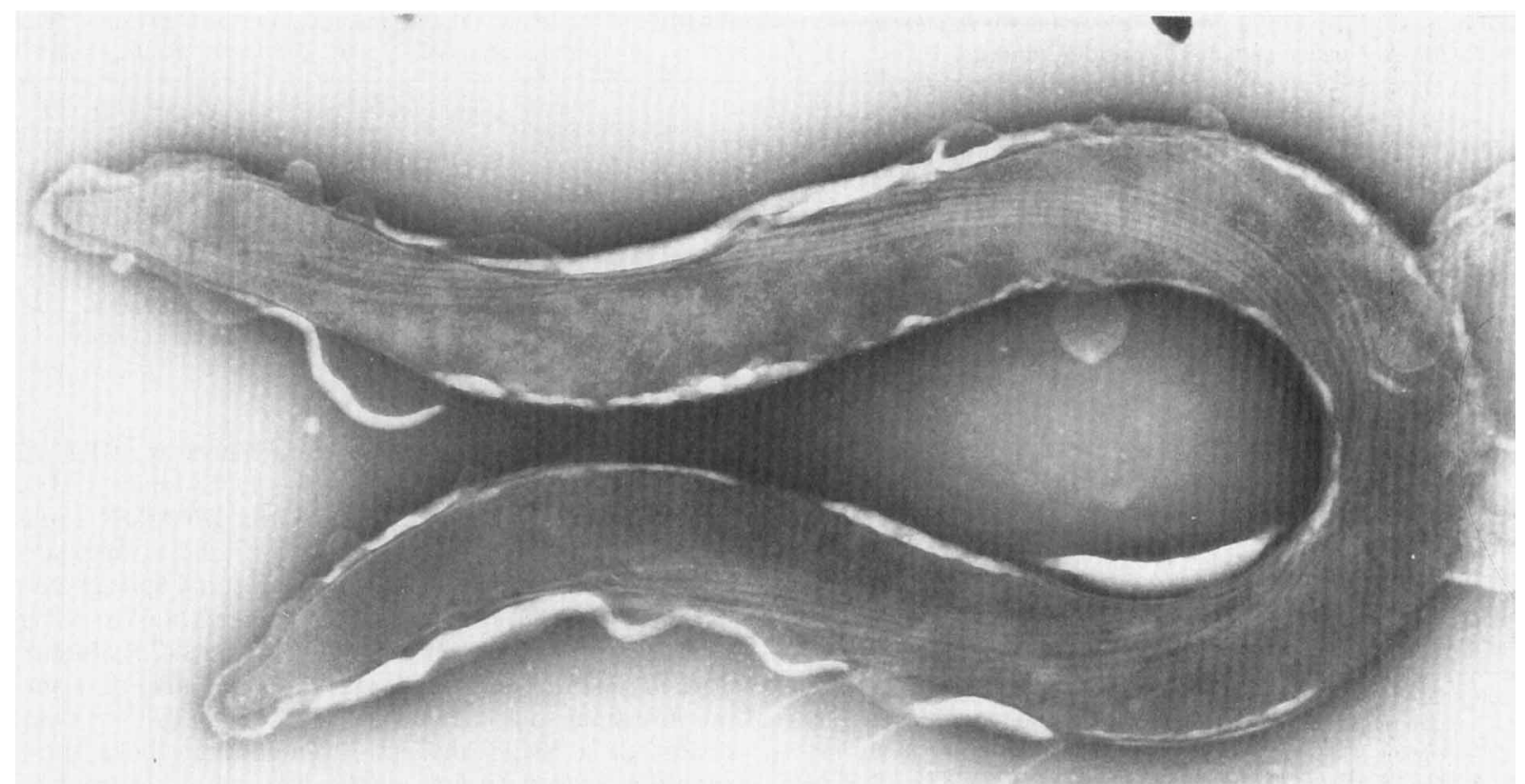

A

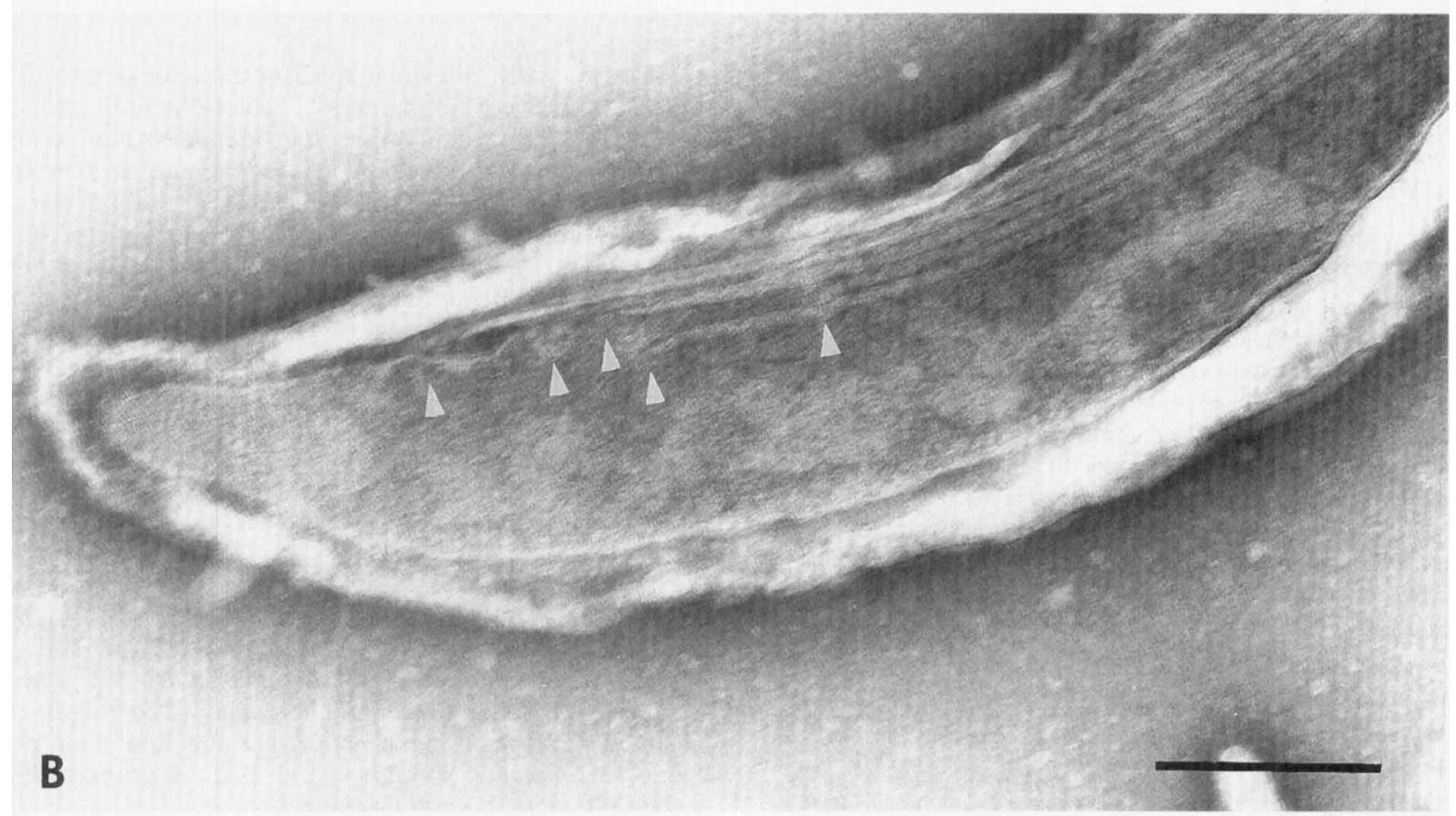

FIG. 3. (A) Electron micrograph of a negatively stained whole cell of $S$. pilosicoli $\mathrm{P} 43 / 6 / 78^{\mathrm{T}}$. The ends of the cell are pointed. Bar $=0.5 \mu \mathrm{m}$. (B) Electron micrograph of one end of a cell, showing five flagella and insertion discs in a row. Bar $=0.2 \mu \mathrm{m}$.

density). In separate experiments, $\mathrm{P} 43 / 6 / 78^{\mathrm{T}}$ cells yielded the same end products in similar proportions when D-ribose was used in place of D-glucose as the carbohydrate source. When no substrate was included, $\mathrm{P} 43 / 6 / 78^{\mathrm{T}}$ cells produced acetate, ethanol, $\mathrm{H}_{2}$, and $\mathrm{CO}_{2}$ and did not produce butyrate.

Antibiotic susceptibility. The antibiotic susceptibilities of the three spirochete strains are shown in Table 1. Similar susceptibility patterns were obtained for all three strains with each antibiotic, although $S$. innocens $\mathrm{B} 256^{\mathrm{T}}$ and $S$. pilosicoli
$\mathrm{P} 43 / 6 / 78^{\mathrm{T}}$ cells were susceptible to lower concentrations of ampicillin, kanamycin, nalidixic acid, novobiocin, rifampin, spiramycin, and tylosin than strain $\mathrm{B} 78^{\mathrm{T}}$ cells were.

DNA analysis. The relative levels of DNA-DNA reassociation are shown in Table 5. Moderate levels of sequence homology were observed between the DNAs of $S$. hyodysenteriae $\mathrm{B} 78^{\mathrm{T}}$ and $S$. innocens $\mathrm{B} 256^{\mathrm{T}}$ (46 and $38 \%$ ). S. pilosicoli $\mathrm{P} 43 / 6$ / $78^{\mathrm{T}}$ DNA exhibited 24 to $25 \%$ homology with strain $\mathrm{B} 78^{\mathrm{T}}$ DNA and 26 to $32 \%$ homology with strain B256 ${ }^{\mathrm{T}}$ DNA. As 
TABLE 3. Comparison of growth substrates for S. pilosicoli $\mathrm{P} 43 / 6 / 78^{\mathrm{T}}, S$. hyodysenteriae $\mathrm{B} 78^{\mathrm{T}}$, and $S$. innocens $\mathrm{B} 256^{\mathrm{T}}$

\begin{tabular}{|c|c|c|c|}
\hline \multirow{2}{*}{ Compound $^{a}$} & \multicolumn{3}{|c|}{ Growth response $^{b}$} \\
\hline & $\begin{array}{l}\text { S. pilosicoli } \\
\mathrm{P} 43 / 6 / 78^{\mathrm{T}}\end{array}$ & $\begin{array}{c}\text { S. hyodysenteriae } \\
\text { B } 78^{\mathrm{Tc}}\end{array}$ & $\begin{array}{l}\text { S. innocens } \\
\text { B } 256^{\mathrm{T}}\end{array}$ \\
\hline None & $(1.0)$ & $(0.35)$ & $(0.60)$ \\
\hline D-Glucose & $+(\geq 2.0)$ & $+(1.3)$ & $+(1.5)$ \\
\hline D-Fructose & $+(\geq 2.0)$ & $+(1.3)$ & $+(1.4)$ \\
\hline Sucrose & $+(\geq 2.0)$ & $+(1.3)$ & $+(1.2)$ \\
\hline D-Trehalose & $+(\geq 2.0)$ & $+(1.3)$ & $+(1.2)$ \\
\hline D-Galactose & $+(1.5)$ & $+(0.6)$ & $+(0.85)$ \\
\hline D-Mannose & $+(1.6)$ & $+(0.7)$ & $+(1.0)$ \\
\hline Maltose & $+(1.5)$ & $+(0.6)$ & $+(1.2)$ \\
\hline $\begin{array}{l}N \text {-Acetyl-D-glucos- } \\
\text { amine }\end{array}$ & $+(\geq 2.0)$ & $+(1.2)$ & $+(1.4)$ \\
\hline D-Glucosamine & $+(1.8)$ & $+(1.1)$ & $+(1.2)$ \\
\hline Pyruvate & $+(1.5)$ & $+(0.9)$ & $+(0.9)$ \\
\hline L-Fucose & $+(1.5)$ & - & $+(0.9)$ \\
\hline D-Cellobiose & $+(\geq 2.0)$ & - & $+(1.3)$ \\
\hline D-Ribose & $+(\geq 2.0)$ & - & - \\
\hline
\end{tabular}

${ }^{a}$ The substrates that were not metabolized by any isolate included $\mathrm{L}$-arabinose, D-fucose, D-raffinose, D-melibiose, L-rhamnose, D-xylose, galactosamine, $N$-acetylgalactosamine, cellulose, esculin, soluble starch, pectin, mucin, glycogen, polygalacturonic acid, glutathione, glycerol, mannitol, acetate, lactate, succinate and $50 \times$ MEM amino acids.

${ }^{b}$-, no detectable growth above the background level in medium without added substrate; + , substrate utilized by growing cells. The numbers in parentheses are the maximum culture $\mathrm{OD}_{620}$ values obtained in media containing the substrates.

${ }^{c}$ Data from reference 36

determined by the thermal denaturation method, the $\mathrm{G}+\mathrm{C}$ contents of the DNAs of $S$. pilosicoli $\mathrm{P} 43 / 6 / 78^{\mathrm{T}}$ and $S$. hyodysenteriae $\mathrm{B} 78^{\mathrm{T}}$ were 24.6 and $25.9 \mathrm{~mol} \%$, respectively.

\section{DISCUSSION}

The intestinal spirochetes that form weakly beta-hemolytic colonies on Trypticase soy blood agar have not been well characterized and, except for Brachyspira aalborgi (11) and $S$. innocens $(18,33)$, have not been given official taxonomic designations previously. As determined by DNA-DNA relative reassociation experiments, the only strains identified as $S$. innocens strains are strains B256 ${ }^{\mathrm{T}}$ and $4 / 71(33,35)$. Swine intestinal spirochete strain $\mathrm{P} 43 / 6 / 78^{\mathrm{T}}$ and other strains of weakly beta-hemolytic intestinal spirochetes have been compared by

TABLE 4. End products of growing cells of $S$. pilosicoli $\mathrm{P} 43 / 6 / 78^{\mathrm{T}}$, $S$. hyodysenteriae $\mathrm{B} 78^{\mathrm{T}}$, and $S$. innocens $\mathrm{B} 256^{\mathrm{T}}$

\begin{tabular}{|c|c|c|c|}
\hline \multirow[b]{2}{*}{ Product ${ }^{a}$} & \multicolumn{3}{|c|}{ Amt produced $(\mu \mathrm{mol} / \mathrm{ml} \text { of medium })^{b}$} \\
\hline & $\begin{array}{l}\text { S. pilosicoli } \\
\mathrm{P} 43 / 6 / 78^{\mathrm{T}}\end{array}$ & $\begin{array}{c}\text { S. hyodysenteriae } \\
\mathrm{B} 78^{\mathrm{T} c}\end{array}$ & $\begin{array}{l}\text { S. innocens } \\
{ }_{\mathrm{B} 256^{\mathrm{T}}}\end{array}$ \\
\hline Acetate & 23.3 & 12.0 & 18.0 \\
\hline Butyrate & 1.5 & 1.7 & 1.8 \\
\hline Ethanol & 2.4 & $\mathrm{ND}^{d}$ & 0.9 \\
\hline $\mathrm{CO}_{2}$ & 11.3 & 10.3 & 13.1 \\
\hline $\mathrm{H}_{2}$ & 22.4 & 24.0 & 22.0 \\
\hline
\end{tabular}

${ }^{a}$ The following compounds were assayed for but were not produced by any strain: formate, lactate, propionate, isobutyrate, valerate, succinate, butanol, and propanol.

${ }^{b}$ The culture medium used was HS broth supplemented with $0.4 \%$ glucose, and the atmosphere was $1 \% \mathrm{O}_{2}-99 \% \mathrm{~N}_{2} . \mathrm{O}_{2}(1 \%)$ injected into the headspace atmosphere before inoculation was completely consumed by all three strains. The amount of oxygen consumed was estimated to be $2 \mu \mathrm{mol} / \mathrm{ml}$ of culture broth.

${ }^{c}$ Data from reference 36.

${ }^{d} \mathrm{ND}$, not detected.
TABLE 5. Levels of relative reassociation of $S$. pilosicoli $\mathrm{P} 43 / 6 / 78^{\mathrm{T}}$, S. hyodysenteriae $\mathrm{B} 78^{\mathrm{T}}$, and $S$. innocens $\mathrm{B} 256^{\mathrm{T}}$ DNAs

\begin{tabular}{|c|c|c|c|}
\hline \multirow{2}{*}{$\begin{array}{c}\text { Source of labeled } \\
\text { DNA }\end{array}$} & \multicolumn{3}{|c|}{$\%$ Reassociation with unlabeled DNA from ${ }^{a}$ : } \\
\hline & $\begin{array}{l}\text { S. pilosicoli } \\
\mathrm{P} 43 / 6 / 78^{\mathrm{T}}\end{array}$ & $\begin{array}{c}\text { S. hyodysenteriae } \\
\mathrm{B} 78^{\mathrm{T}}\end{array}$ & $\begin{array}{l}\text { S. innocens } \\
\text { B256 }{ }^{\mathrm{T}}\end{array}$ \\
\hline S. pilosicoli $\mathrm{P} 43 / 6 / 78^{\mathrm{T}}$ & 100 & 25 & 26 \\
\hline S. hyodysenteriae $\mathrm{B} 78^{\mathrm{T}}$ & 24 & 100 & 46 \\
\hline S. innocens $\mathrm{B} 256^{\mathrm{T}}$ & 32 & 38 & 100 \\
\hline
\end{tabular}

${ }^{a}$ Reassociation values were determined by the $\mathrm{S} 1$ nuclease method $(15,17)$.

performing multilocus enzyme electrophoresis (MEE) $(23,25)$ and a random amplified polymorphic DNA analysis (3), as well as phenotypic characterization (5) and DNA-DNA reassociation $(3,26,30)$ analyses. The results of these studies suggested that $\mathrm{P} 43 / 6 / 78^{\mathrm{T}}$ is related to other intestinal spirochete strains that have 8 to 12 periplasmic flagella per cell ( 4 to 6 flagella at each end) and have been isolated from pigs (25), humans (23), dogs $(2,3)$, and birds $(28)$ with intestinal disorders similar to the intestinal spirochetosis caused by $\mathrm{P} 43 / 6 / 78^{\mathrm{T}}$ in swine. The results of a MEE analysis revealed that these spirochetes should be placed within a single electrophoretic group $(23,28)$. Since the electrophoretic profiles of the spirochetes in this group were distinct from those of $S$. innocens, $S$. hyodysenteriae, and $B$. aalborgi, the provisional name "Anguillina coli" was suggested for $\mathrm{P} 43 / 6 / 78^{\mathrm{T}}$ and the other closely related spirochetes $(23,25)$.

More recently, intestinal spirochetes belonging to different MEE groups were compared in a $16 \mathrm{~S}$ rRNA sequence analysis (38). It was found that swine intestinal spirochete strain P43/ $6 / 78^{\mathrm{T}}$ and two other intestinal spirochete strains (human strains HRM-7 and Wes-B) belonging to the " $A$. coli" MEE group exhibited 99.7 to $99.8 \% 16 \mathrm{~S}$ rRNA sequence similarity with each other and 98 to $98.6 \% 16 \mathrm{~S}$ rRNA sequence similarity with $S$. hyodysenteriae $\mathrm{B} 78^{\mathrm{T}}$ and $S$. innocens $\mathrm{B} 256^{\mathrm{T}}$. These results supported the results of Fellström and coworkers, who determined partial $16 \mathrm{~S}$ ribosomal DNA sequences for members of a heterogeneous group of porcine intestinal spirochetes and suggested that the isolates placed in the " $A$. coll" group exhibited high levels of sequence homology with $S$. hyodysenteriae and $S$. innocens (6). S. hyodysenteriae $\mathrm{B} 78^{\mathrm{T}}$ and $S$. innocens $\mathrm{B} 256^{\mathrm{T}}$ exhibited $99.5 \%$ 16S rRNA sequence similarity with each other and 72.7 to $76.1 \%$ 16S rRNA sequence similarity with the gastrointestinal spirochetes Treponema bryantii RUS- $1^{\mathrm{T}}$ and Treponema succinifaciens $6091^{\mathrm{T}}(35)$. On the basis of these results, it was suggested that the " $A$. coli" group should be considered a Serpulina species $(6,38)$. It was also recommended that these spirochetes should be investigated for distinguishing phenotypic properties and that their phylogenetic relationships should be assessed by other techniques, especially DNA homology estimates (38).

On the basis of the results of previous investigations and the findings of this study, we concluded that intestinal spirochete strain P43/6/78 should be assigned to the genus Serpulina and represents a distinct species, for which we propose the name Serpulina pilosicoli. Strain P43/6/78 (= ATCC 51139) is the type strain of $S$. pilosicoli.

$S$. pilosicoli $\mathrm{P} 43 / 6 / 78^{\mathrm{T}}$ has a number of genomic and phenotypic properties in common with $S$. hyodysenteriae and $S$. innocens. The $16 \mathrm{~S}$ rRNA sequences of these spirochetes are similar (levels of similarity, 98.2 to $99.5 \%$ ) (38), and the $\mathrm{G}+\mathrm{C}$ contents of their DNAs are also similar (24 to $26 \mathrm{~mol} \%$ ). All three species use soluble sugars, amino sugars, and pyruvate for growth (Table 3); consume $\mathrm{O}_{2}$ in substrate amounts; and pro- 
duce acetate, butyrate, $\mathrm{H}_{2}$, and $\mathrm{CO}_{2}$ during glucose metabolism (Table 4). Interestingly, the ratio of $\mathrm{H}_{2}$ to $\mathrm{CO}_{2}$ is $2: 1$, suggesting that all three spirochetes have NADH:ferredoxin oxidoreductase activity (32). These organisms are aerotolerant anaerobes that can grow in atmospheres that initially contain 1 to $5 \%$ (vol $/ \mathrm{vol}) \mathrm{O}_{2}$, and they possess NADH oxidase (34) and superoxide dismutase activities (23). The level of DNA-DNA relative reassociation between $\mathrm{P} 43 / 6 / 78^{\mathrm{T}}$ and either $S$. hyodysenteriae $\mathrm{B} 78^{\mathrm{T}}$ or $S$. innocens $\mathrm{B} 256^{\mathrm{T}}$ is 24 to $36 \%$, and the levels of DNA-DNA reassociation between $S$. hyodysenteriae B $78^{\mathrm{T}}$ and $S$. innocens $\mathrm{B} 256^{\mathrm{T}}$ are 38 to $46 \%$ (Table 5 ). In a previous study, the swine intestinal spirochete $T$. succinifaciens $6091^{\mathrm{T}}$ exhibited $2 \%$ DNA-DNA relative reassociation with $S$. hyodysenteriae $\mathrm{B} 78^{\mathrm{T}}(35)$. Although a standard range of DNA homology values has not been established, 24 to $46 \%$ seems to be a reasonable range of DNA homology values for including strains in the same genus. We believe that the characteristics described above support placement of strain $\mathrm{P} 43 / 6 / 78^{\mathrm{T}}$ in the genus Serpulina.

S. pilosicoli $\mathrm{P} 43 / 6 / 78^{\mathrm{T}}$ cells superficially resemble $B$, aalborgi $513 \mathrm{~A}^{\mathrm{T}}$ cells in that both spirochetes have fewer than six periplasmic flagella inserted at each end of each cell and produce weakly beta-hemolytic colonies $(11,23)$. Unfortunately, the physiological and biochemical properties of $B$. aalborgi have not been studied in sufficient detail to allow comparisons between this human intestinal spirochete and other species of intestinal spirochetes (11). B. aalborgi $513 \mathrm{~A}^{\mathrm{T}}$ exhibited $96.5 \%$ $16 \mathrm{~S}$ rRNA sequence homology with $S$. hyodysenteriae $\mathrm{B} 78^{\mathrm{T}}$ and $S$. innocens $\mathrm{B}^{256^{\mathrm{T}}}(10,38)$ and $96.3 \%$ 16S rRNA sequence homology with $S$. pilosicoli $\mathrm{P} 43 / 6 / 78^{\mathrm{T}}(38)$. The MEE profile of B. aalborgi $513 \mathrm{~A}^{\mathrm{T}}$ is distinct from the MEE profiles of other intestinal spirochetes (23). While the $16 \mathrm{~S}$ rRNA sequence data suggest that $B$. aalborgi $513 \mathrm{~A}^{\mathrm{T}}$ is phylogenetically related to species of intestinal spirochetes belonging to the genus Serpulina $(10,38)$, additional methods of comparison (for example, DNA-DNA relative reassociation and more extensive phenotypic characterization) will have to be used before the genetic relatedness of $B$. aalborgi and the other intestinal spirochetes can be fully evaluated.

Phenotypic characteristics that distinguish $S$. pilosicoli $\mathrm{P} 43 /$ $6 / 78^{\mathrm{T}}$ from $S$. hyodysenteriae $\mathrm{B} 78^{\mathrm{T}}$ and $S$. innocens $\mathrm{B} 256^{\mathrm{T}}$ are shown in Table 2 . Under the same conditions, $S$. pilosicoli $\mathrm{P} 43 / 6 / 78^{\mathrm{T}}$ cells were smaller, had fewer flagella, and grew more rapidly than the cells of the other species. Ribose was the only growth substrate that distinguished $S$. pilosicoli $\mathrm{P} 43 / 6 / 78^{\mathrm{T}}$ from $S$. hyodysenteriae $\mathrm{B} 78^{\mathrm{T}}$ and $S$. innocens $\mathrm{B} 256^{\mathrm{T}}$. Only $S$. pilosicoli cells hydrolyzed hippurate and were beta-glucosidase negative, two biochemical characteristics that have been used by previous researchers to distinguish intestinal spirochetes associated with intestinal spirochetosis $(3,5)$. Once additional $S$. pilosicoli strains are identified by genomic and phylogenetic comparisons with $\mathrm{P} 43 / 6 / 78^{\mathrm{T}}$, it will be possible to assess whether these phenotypic properties are unique to $S$. pilosicoli and thus are useful for identifying this new species.

At this time, the most clear-cut method for differentiating $S$. hyodysenteriae, $S$. innocens, and $S$. pilosicoli is the DNA-DNA relative reassociation method $(3,35)$. Analyses and comparisons of 16S rRNA sequences are both useful and essential for classifying spirochetes on the "Serpulina-Brachyspira" branch of the 16S rRNA dendrogram. The $16 \mathrm{~S}$ rRNA sequence of $S$. pilosicoli $\mathrm{P} 43 / 6 / 78^{\mathrm{T}}$ contains a short "signature" sequence of nucleotides which has been used to design a PCR that is specific for other human and porcine spirochetes associated with intestinal spirochetosis (29). However, 16S rRNA sequence analysis alone cannot be used to differentiate species within the genus Serpulina, as all spirochete strains that have been char- acterized thus far exhibit significant levels of 16S rRNA sequence identity (38). On the basis of MEE analysis results, $S$. pilosicoli $\mathrm{P} 43 / 6 / 78^{\mathrm{T}}$ was assigned (along with other porcine and human strains) to an electrophoretic group (group VI) which was distinct from the electrophoretic groups containing $S$. hyodysenteriae strains (group I) and $S$. innocens strains (group III) $(23,38)$. However, at this time, it has not been established whether all of the spirochetes belonging to electrophoretic group VI belong to a single species (i.e., are $S$. pilosicoli strains) (23).

S. pilosicoli $\mathrm{P} 43 / 6 / 78^{\mathrm{T}}$ is a pathogenic spirochete that causes porcine intestinal spirochetosis, a diarrheal disease of swine characterized by the attachment of large numbers of spirochetes by one end to the colonic epithelium. Recent studies have revealed that other intestinal spirochete strains recovered from intestinal spirochetosis-like conditions in pigs $(5,6,25$, 30 ), humans $(23,26)$, birds $(28)$, and dogs $(2,3)$ are related to $S$. pilosicoli $\mathrm{P} 43 / 6 / 78^{\mathrm{T}}$. It has recently been shown that some of these strains (human intestinal spirochete strain WesB and porcine intestinal spirochete strain 1648) attach by one end to the colonic epithelium and cause watery diarrhea and stunting in 1-day-old specific-pathogen-free chicks (41). Additional analyses of these spirochetes to determine their phylogenetic, genomic, and phenotypic similarities to $S$. pilosicoli $\mathrm{P} 43 / 6 / 78^{\mathrm{T}}$ should reveal whether $S$. pilosicoli is an enteropathogenic spirochete with a broad host range. It will be particularly important to determine if all human intestinal spirochetes that are distinct from the nonpathogenic organism $B$. aalborgi belong to S. pilosicoli, as such a finding would support previous suggestions that these organisms may act as diarrheal agents $(23,41)$. Such studies are currently in progress.

Description of Serpulina pilosicoli sp. nov. Serpulina pilosicoli (pi.lo.si'co.li.) L. adj. pilosum, hairy, napped, shaggy; $\mathrm{G}$ neu ${ }^{+}$. n. colon, colon; N. L. gen. n. pilosicoli, of a hairy colon (referring to the fact that infection and attachment by this intestinal spirochete [intestinal spirochetosis] result in a microscopic appearance that resembles a hairy covering on the surface of the colon). Typical morphology and motility of members of the genus Serpulina. Cells are 4 to $12 \mu \mathrm{m}$ long and 0.2 to $0.3 \mu \mathrm{m}$ in diameter. There are 8,10 , or occasionally 12 periplasmic flagella per cell; 4 to 6 periplasmic flagella are inserted at each end of each cell, and free ends of these flagella overlap in the middle of the cell. At least one end of each cell tapers abruptly to a distinct point. Weakly beta-hemolytic on Trypticase soy blood agar. Isolated from swine with diarrhea (40).

Enteropathogenic when pure cultures are inoculated orally into swine (40). Each cell attaches by one end to the colonic epithelium. Causes watery, mucoid diarrhea (40). Similar strains may cause diarrhea in humans (26), dogs (3), and poultry $(28)$.

Grows at 37 to $42^{\circ} \mathrm{C}$ in Trypticase soy broth or brain heart infusion broth supplemented with serum (minimum concentration, $7 \%)$ in the presence of an $\mathrm{O}_{2}-\mathrm{N}_{2}(1: 99)$ atmosphere and reaches a maximum culture density of $2 \times 10^{9}$ cells per ml. Tolerates low $\mathrm{O}_{2}$ tensions $(<7 \%)$ in sealed culture tubes and consumes substrate amounts of $\mathrm{O}_{2}$. NADH oxidase positive (37). The population doubling time is 1 to $2 \mathrm{~h}$ in BHIS broth at $38^{\circ} \mathrm{C}$.

The growth substrates utilized include D-glucose, D-fructose, sucrose, D-trehalose, $N$-acetyl-D-glucosamine, D-glucosamine, Dmannose, maltose, pyruvate, L-fucose, D-cellobiose, and D-ribose. The substrates that do not support growth include L-arabinose, D-fucose, D-raffinose, D-melibiose, L-rhamnose, D-xylose, galactosamine, $\mathrm{N}$-acetylgalactosamine, cellulose, esculin, soluble starch, pectin, mucin, glycogen, glucuronic acid, polygalacturonic acid, glutathione, glycerol, mannitol, acetate, lactate, 
succinate, and amino acids. Limited growth occurs in HS broth supplemented with the minimum concentration of serum required and no additional substrate.

Hydrolyzes hippurate. Negative for indole. $\alpha$-Glucosidase negative, $\alpha$-galactosidase positive, and $\beta$-glucosidase negative. Growing cells produce acetate $(23.3 \mu \mathrm{mol} / \mathrm{ml}$ of medium), small amounts of butyrate and ethanol $(1.5$ and $2.4 \mu \mathrm{mol} / \mathrm{ml}$ of medium, respectively $), \mathrm{CO}_{2}(11.3 \mu \mathrm{mol} / \mathrm{ml}$ of medium $)$, and $\mathrm{H}_{2}$ $(22.4 \mu \mathrm{mol} / \mathrm{ml}$ of medium $)$ in HS broth supplemented with $0.4 \%$ glucose in the presence of an $\mathrm{O}_{2}-\mathrm{N}_{2}(1: 99)$ atmosphere.

Susceptible to ampicillin, carbadox, chloramphenicol, lincomycin, metronidazole, tetracycline, tiamulin, and tylosin. Moderately susceptible to erythromycin, kanamycin, neomycin, novobiocin, rifampin, spiramycin, and streptomycin. Resistant to colistin, nalidixic acid, polymixin B, spectinomycin, and vancomycin.

Exhibits 24 to $25 \%$ DNA homology with $S$. hyodysenteriae $\mathrm{B} 78^{\mathrm{T}}$ and 26 to $32 \%$ DNA homology with $S$. innocens $\mathrm{B} 256^{\mathrm{T}}$ as determined by the $\mathrm{S} 1$ nuclease method. The $\mathrm{G}+\mathrm{C}$ content of strain $\mathrm{P} 43 / 6 / 78^{\mathrm{T}}$ DNA is $25 \pm 1 \mathrm{~mol} \%$ (as determined by the thermal denaturation method). Exhibits $98.5 \% 16 \mathrm{~S}$ rRNA sequence homology with $S$. hyodysenteriae $\mathrm{B}^{\mathrm{T}}{ }^{\mathrm{T}}$ and $99.2 \% 16 \mathrm{~S}$ rRNA sequence homology with $S$. innocens $\mathrm{B} 256^{\mathrm{T}}$. Has a unique $16 \mathrm{~S}$ rRNA signature sequence $\left(5^{\prime}\right.$-AGUUUUUUCGC UUCA-3') (29).

The type strain is strain $\mathrm{P} 43 / 6 / 78$, which has been deposited in the American Type Culture Collection as strain ATCC 51139 .

\section{ACKNOWLEDGMENTS}

This work was funded by the Australian Pig Research and Development Corporation, the Australian Research Council, and Murdoch University. D.J.T. was the recipient of an Australian Pig Research and Development Corporation postgraduate scholarship.

We thank Sophy Oxberry, Sam Humphrey, Herb Cook, Judi Stasko, Michelle R. Mathiesen, and Julianna Toth for providing technical assistance. We gratefully acknowledge the assistance of Judith Maitland, Arts Department, University of Western Australia, Perth, Western Australia, Australia, and Thomas McAdoo, Department of Foreign Languages and Literatures, Virginia Polytechnic Institute and State University, Blacksburg, who helped us select the specific epithet of $S$. pilosicoli and provided advice regarding nomenclature.

\section{REFERENCES}

1. Andrews, J. J., and L. J. Hoffman. 1982. A porcine colitis caused by a weakly $\beta$-hemolytic treponeme (Treponema innocens?), p. 395-402. In Proceedings of the 25th American Association of Veterinary Laboratory Diagnosticians, Nashville, Tenn.

2. Duhamel, G. E., B. D. Hunsaker, M. R. Mathieson, and R. A. Moxley. Intestinal spirochaetosis and giardiasis in a beagle pup with diarrhoca. Vet. Pathol., in press.

3. Duhamel, G. E., N. Muniappa, M. R. Mathieson, J. L. Johnson, J. Toth, R. O. Elder, and A. R. Doster. 1995. Certain canine weakly $\beta$-hemolytic intestinal spirochetes are phenotypically and genotypically related to spirochetes associated with human and porcine intestinal spirochetosis. J. Clin. Microbiol. 33:2212-2215.

4. Duhamel, G. E., M. Ramanathan, I. Gardner, M. A. Anderson, R. L. Walker, and D. J. Hampson. 1993. Intestinal spirochetosis of swine associated with weakly $\beta$-hemolytic spirochetes distinct from Serpulina innocens, p. 53. In Proceedings of the 36th American Association of Veterinary Laboratory Diagnosticians, Las Vegas, Nev.

5. Fellström, C., and A. Gunnarsson. 1995. Phenotypic characterisation of intestinal spirochaetes isolated from pigs. Res. Vet. Sci. 59:1-4.

6. Fellström, C., B. Pettersson, M. Uhlén, A. Gunnarsson, and K. Johansson. 1995. Phylogeny of Serpulina based on sequence analyses of the 16S rRNA gene and comparison with a scheme involving biochemical classification. Res. Vet. Sci. 59:5-9.

7. Girard, C., T. Lemarchand, and R. Higgins. 1995. Porcine colonic spirochetosis: a retrospective study of eleven cases. Can. Vet. J. 36:291-294.

8. Harland, W. A., and F. D. Lee. 1967. Intestinal spirochaetosis. Br. Med. J. 3: $718-719$.

9. Holdeman, L. V., E. P. Cato, and W. E. C. Moore (ed.). 1977. Anaerobic laboratory manual. Anaerobe Laboratory, Virginia Polytechnic Institute and State University, Blacksburg.

10. Hookey, J. V., S. P. Barrett, C. S. Read, and P. Barber. 1994. Phylogeny of the human intestinal spirochetes inferred from 16S rDNA sequence comparisons. FEMS Microbiol. Lett. 117:345-350.

11. Hovind-Hougen, K., A. Birch-Andersen, R. Henrik-Nielsen, M. Orholm, J. O. Pedersen, P. S. Teglbjærg, and E. H. Thaysen. 1982. Intestinal spirochetosis: morphological characterization and cultivation of the spirochete Brachyspira aalborgi gen. nov., sp. nov. J. Clin. Microbiol. 16:1127-1136.

12. Hovind-Hougen, K., P. Hagh, and A. Birch-Andersen. 1990. Morphological heterogeneity among spirochetes isolated from cases of swine dysentery. Zentralbl. Bakteriol. Parasitenkd. Infektionskr. Hyg. Abt. 1 Orig. 274:1-15.

13. Hunter, D., and T. Wood. 1979. An evaluation of the API ZYM system as a means of classifying spirochaetes associated with swine dysentery. Vet. Rec. 104:383-384.

14. Jacques, C., C. Girard, R. Higgins, and G. Goyette. 1989. Extensive colonization of the porcine colonic epithelium by a spirochete similar to Treponema innocens. J. Clin. Microbiol. 27:1139-1141.

15. Johnson, J. L. 1985. DNA reassociation and RNA hybridization of bacterial nucleic acids. Methods Microbiol. 18:33-74.

16. Johnson, J. L. 1994. Similarity analysis of DNAs, p. 655-682. $\ln$ P. Gerhardt, R. G. E. Murray, W. A. Wood, and N. R. Krieg (ed.), Methods for general and molecular bacteriology. American Society for Microbiology, Washington, D.C.

17. Johnson, J. L., C. F. Phelps, C. S. Cummins, J. London, and F, Gasser. 1980. Taxonomy of the Lactobacillus acidophilus group. Int. J. Syst. Bacteriol. 30: 53-68.

18. Kinyon, J. M., and D. L. Harris. 1979. Treponema innocens, a new species of intestinal bacteria, and emended description of the type strain of Treponema hyodysenteriae. Harris et al. Int. J. Syst. Bacteriol. 29:102-109.

19. Kitai, K., M. Kashiwazaki, Y. Adachi, T. Kume, and A. Arakawa. 1979. In vitro activity of 39 antimicrobial agents against Treponema hyodysenteriae. Antimicrob. Agents Chemother. 15:392-395.

20. Kleiner, D. E., and W. G. Stetler-Stevenson. 1994. Quantitative zymography: detection of picogram quantities of gelatinases. Anal. Biochem. 218:325-329.

21. Kunkle, R. A., and J. M. Kinyon. 1988. Improved selective medium for the isolation of Treponema hyodysenteriae. J. Clin. Microbiol. 26:2357-2360.

22. Lee, F. D., A. Kraszewski, J. Gordon, J. G. R. Howie, D. MeSeveney, and W. A. Harland. 1971. Intestinal spirochaetosis. Gut 12:126-133.

23. Lee, J. I., and D. J. Hampson. 1994. Genetic characterisation of intestinal spirochaetes, and their association with disease. J. Med. Microbiol. 40:365371.

24. Lee, J. I., D. J. Hampson, B. G. Combs, and A. J. Lymbery. 1993. Genetic relationships between isolates of Serpulina (Treponema) hyodysenteriae, and comparison of methods for their subspecific differentiation. Vet. Microbiol. 34:35-46.

25. Lee, J. I., D. J. Hampson, A. J. Lymbery, and S. J. Harders. 1993. The porcine intestinal spirochaetes: identification of new genetic groups. Vet. Microbiol. 34:273-285.

26. Lee, J. I., A. J. McLaren, A. J. Lymbery, and D. J. Hampson. 1993. Human intestinal spirochaetes are distinct from Serpulina hyodysenteriae. J. Clin. Microbiol. 31:16-21.

27. Mandel, M., and J. Marmur. 1968. Use of ultraviolet absorbance-temperature profile for determining the guanine plus cytosine content of DNA. Methods Enzymol. 12:195-206

28. McLaren, A. J., D. J. Trott, D. E. Swayne, J. W. Stoutenburg, and D. J. Hampson. 1994. Characterization of avian intestinal spirochetes, p. 66. In Proceedings of the North Central Avian Disease Congress, Des Moines, Iowa.

29. Park, N. Y., C. Y. Chung, A. J. McLaren, R. F. Atyeo, and D. J. Hampson. 1995. Polymerase chain reaction for identification of human and porcine spirochaetes recovered from cases of intestinal spirochaetosis. FEMS Mispirochaetes recovered from

30. Ramanathan, M., G. E. Duhamel, M. R. Mathiesen, and S. Messier. 1993. Identification and partial characterisation of a group of weakly $\beta$-hemolytic intestinal spirochetes of swine distinct from Serpulina innocens isolate B256. Vet. Microbiol. 37:53-64.

31. Spearman, J. G., G. Nayar, and M. Sheridan. 1988. Colitis associated with Treponema innocens in pigs. Can. Vet. J. 29:747.

32. Stanton, T. B. 1989. Glucose metabolism and NADH recycling by Treponema hyodysenteriae, the agent of swine dysentery. Appl. Environ. Microbiol. 55:2365-2371.

33. Stanton, T. B. 1992. Proposal to change the genus designation Serpulina to Serpulina gen. nov. containing the species Serpulina hyodysenteriae comb. nov. and Serpulina innocens comb. nov. Int. J. Syst. Bacteriol. 42:189-192.

34. Stanton, T. B., B. L. Hanzelka, and N. S. Jensen. 1995. Survey of intestinal spirochetes for NADH oxidase activity. Microb. Ecol. Health Dis. 8:93-100.

35. Stanton, T. B., N. S. Jensen, T. A. Casey, L. A. Tordoff, F. E. Dewhirst, and B. J. Paster. 1991. Reclassification of Treponema hyodysenteriae and Treponema innocens in a new genus, Serpula gen. nov., as Serpula hyodysenteriae comb. nov. and Serpula innocens comb. nov. Int. J. Syst. Bacteriol. 41:50-58.

36. Stanton, T. B., and D. F. Lebo. 1988. Treponema hyodysenteriae growth under 
various culture conditions. Vet. Microbiol. 18:177-190.

37. Stanton, T. B., and D. C. Savage. 1983. Roseburia cecicola gen. nov., sp. nov., a motile, obligately anaerobic bacterium from a mouse cecum. Int. J. Syst. Bacteriol. 33:618-627.

38. Stanton, T. B., D. J. Trott, J. I. Lee, A. J. McLaren, D. J. Hampson, B. J. Paster, and N. S. Jensen. Differentiation of intestinal spirochaetes by multilocus enzyme electrophoresis and 16S rRNA comparisons. Submitted for publication

39. Taylor, D. J. 1992. Spirochaetal diarrhoea, p. 584-587. In A. D. Leman, B. E.
Straw, W. L. Mengeling, S. D'Allaire, and D. J. Taylor (ed.), Diseases of swine. Iowa State University Press, Ames.

40. Taylor, D. J., J. R. Simmons, and H. M. Laird. 1980. Production of diarrhoea and dysentery in pigs by feeding pure cultures of a spirochaete differing from Treponema hyodysenteriae. Vet. Rec. 106:326-332.

41. Trott, D. J., A. J. McLaren, and D. J. Hampson. 1995. Pathogenicity of human and porcine intestinal spirochetes in day-old specific-pathogen-free chicks: an animal model of intestinal spirochetosis. Infect. Immun. 63:37053710 . 